\title{
How to run a writing workshop? On the cultivation of scholarly ethics in 'global' legal education
}

Madelaine Chiam, Sundhya Pahuja and James E K Parker *

\begin{abstract}
This article does two main things. First, it records and shares a methodology for running a writing workshop in the context of trans-national doctoral and post-doctoral legal education. Second, it offers a critical reflection on this methodology, and in doing so draws out some more general lessons for thinking about our roles as scholars and teachers in the contemporary university. Our thesis is that the unusually formal, even stylised, structure of the writing workshops we describe offers participants both an opportunity for detailed feedback on their work, and helps to foster a certain ethics of scholarly conduct. This ethics emphasises the intimacy of scholarly relations on the one hand, and the importance of listening on the other. Such an ethics may be antithetical to some of the more insidious imperatives of the contemporary university.
\end{abstract}

\footnotetext{
* Madelaine Chiam is a lecturer at La Trobe Law School. Sundhya Pahuja is a professor at Melbourne Law School, and Director of the Institute for International Law and the Humanities (IILAH). James E K Parker is a senior lecturer at Melbourne Law School. The authors would like to thank David Kennedy, Karen Engle and Daniel Brinks for their comments on drafts of this article, Balawyn Jones for her editorial assistance, and Melbourne Law School for funding research assistance for this piece.
} 


\subsection{Introduction}

A number of imperatives have converged to foster a particular kind of international residential workshop on legal research. In North America, residential 'Summer Institutes' are common across disciplines, ${ }^{1}$ and graduate student workshops are well established in the legal academy in many countries. Such events are generally arranged according to discipline, method, substantive field, or (in law) jurisdiction. What seems to be appearing with increasing regularity is a new variant: residential workshops for doctoral and early career researchers, run by elite 'global' law schools, which present themselves as a response to the 'globalisation' of legal thought and practice and the challenges specific to 'inter-' or 'trans-' national forms of governance. ${ }^{2}$ More pragmatically, the institution-building functions they perform also answer the growing pressure to form 'global networks', at both a personal and institutional level. ${ }^{3}$

The Association of Transnational Law Schools (ATLAS) has run its week-long 'Agora' at a different law school every year now since 2008. ${ }^{4}$ The Harvard Institute for Global Law and Policy (IGLP) has held a residential 'Workshop' in various locations (Doha, Madrid, Cape Town, Bangkok) annually since 2010. Several other programs with a specifically global orientation have been run across a similar period: for example the Transnational Law Summer Institute at King's College London and the Georgetown Center for Transnational Legal Studies.

There are many ways one could approach a critical consideration of such institutions and events. One would be to analyse them through the lens of the reproduction of (global) hierarchies, ${ }^{5}$ exploring their

1 'Summer Institutes' in relation to international affairs, variously named, have a longer history, at least in the American academy. See for example Eleanor Finch, 'Eighth Annual Summer Institute of International Law and the United Nations' (1955) 49(3) The American Journal of International Law 390; Jerome Cohen, 'Boalt Hall's Summer Workshop for International Legal Studies' (1960) 13(2) Journal of Legal Education 239.

2 For example the IGLP Workshops are said to 'strengthen the next generation of scholars by placing them in collaboration with their global peers': Institute for Global Law and Policy, 2018 IGLP Scholars Workshop (online) <http://iglp.law.harvard.edu/iglp-scholars-workshop/> (last accessed 6 July 2018). The 2018 King's Transnational Law Summit, for example, described itself as 'a challenging and thought-provoking agenda creating space for transnational conversations, networking and long-term collaborations across different disciplines and professions': King's College London, About KTLS18 (online) <http://www.transnationallawsummit.org/> (last accessed 6 July 2018).

${ }^{3}$ Margaret Thornton, 'Academic Un-freedom in the new knowledge economy' in Angela Brew and Lisa Lucas (eds), Academic Research and Researchers (McGraw-Hill Education 2009) 19-34.

${ }^{4}$ Phillip Bevans and John McKay, 'The Association of Transnational Law Schools' Agora: An Experiment in Graduate Legal Pedagogy' (2009) 10 German Law Journal 929.

${ }^{5}$ Duncan Kennedy, 'Legal Education and the Reproduction of Hierarchy' (1982) 32 Journal of Legal Education 591. 
relationship to the reproduction of transnational elites. ${ }^{6}$ A second would be to focus on the 'network', and to ask whether it is a form of association that tends toward the imperial, and/or whether the form can be mobilised or subverted to serve solidaristic ends. ${ }^{7}$ A third line of enquiry could treat these events as rich sites for the examination of the question of how education, and educational practices are increasingly being funded, and to consider the effects of private philanthropy and corporate sponsorship on the shape of the intellectual and institutional projects they support. ${ }^{8}$

Another way to approach them though would be to explore their more mundane aspects, the extent to which they operate as a training in conduct, and what specific kind of training they offer. ${ }^{9}$ As with the other possible lines of enquiry, this is a double-edged question. Like all pedagogical practice in universities, workshops and other events run by these organisations have a disciplinary function, in both senses of the word. 'Disciplinary pedagogies' transmit not only 'the academic genres that constitute the theories and practices of the discipline, but also the genres of social relations and embodied subjectivity that construct the discipline as "a body" of knowledge'. ${ }^{10}$ Engagement with them is not simply a take it or leave it proposition, as 'changing any of these [pedagogies], or indeed, leaving them alone, is crucially related to the questions raised by the ... making of literate bodies [and] the disciplining of subjects'. ${ }^{11}$

\footnotetext{
${ }^{6}$ Along the lines of, for example, Yves Dezalay and Bryant Garth, Dealing in Virtue: International Commercial Arbitration and the Constructions of a Transnational Legal Order (University of Chicago Press 1996).

${ }^{7}$ Radha D'Souza, 'The Prison Houses of Knowledge: Activist Scholarship and Revolution in the Era of "Globalization"' (2009) 44(1) McGill Journal of Education 19, 26. See also Cátia Antunes and Amelia Polónia (eds) Beyond Empires: Global, Self-Organizing, Cross-Imperial Networks, 1500-1800 (Brill 2016).

${ }^{8}$ See, for example, the dispute over the proposed Ramsay Centre for Western Civilisation and its place in Australian universities: Australian National University, VC's Update - our viewpoints on Ramsay (online) 25 June 2018 <http://www.anu.edu.au/news/all-news/vcs-update-our-viewpoints-on-ramsay> (last accessed 6 July 2018); Jordan Baker, 'Sydney University academics raise stakes in fight over Ramsay Centre' The Sydney Morning Herald (online) 30 June 2018 <https://www.smh.com.au/education/sydney-university-academics-raise-stakes-in-fight-overramsay-centre-20180629-p4zom0.html> (last accessed 6 July 2018). See also George Monbiot, Captive State: The corporate takeover of Britain (Macmillan 2000).

${ }^{9}$ Pierre Hadot, Philosophy as a Way of Life: Spiritual Exercises from Socrates to Foucault (trans Michael Chase) (Blackwell Publishing 1995); Shaun McVeigh, 'Office and Persona of the Critical Jurist: Peripheral Legal Thought (Australia)' in Justin Desautels-Stein and Chris Tomlins (eds) Searching for Contemporary Legal Thought (Cambridge University Press 2017) 386-405, Ann Genovese, 'Inheriting and Inhabiting the Pleasures and Duties of Our Own Existence: The Second Sex and Feminist Jurisprudence' (2013) 38(1) Australian Feminist Law Journal 41.

${ }^{10}$ Terry Threadgold, 'Everyday Life In the Academy: Postmodernist Feminisms, Generic Seductions, Rewriting and Being Heard' in Carmen Luke (ed) Feminisms and pedagogies of everyday life (State University of New York Press 1996) 281. See also Anne Orford, 'Embodying Internationalism: The Making of International Lawyers' (1998) 19 Australian Year Book of International Law 1.

${ }^{11}$ Threadgold as above at 280.
} 
It is in this last analytical axis that we want to locate this essay, and to offer a report and commentary on our experience of one aspect of residential programs run by two of these globally-minded organisations. That aspect is the 'writing workshop'. And the organisations are the Harvard Institute for Global Law and Policy (IGLP) and the Association of Transnational Law Schools (ATLAS). As a result of their orientations toward the 'global' and the 'transnational' respectively, both the IGLP and ATLAS (like many other such institutional formations) cast their nets deliberately broadly to include participants from a variety of different educational and legal traditions, who sometimes share little in common beyond an interest in 'law' (or governance, regulation or policy) broadly conceived. ${ }^{12}$ Indeed, neither the IGLP nor ATLAS is held together by any of the standard scholarly commitments around which events in the legal academy have historically been organised: that is, by substantive field, method, theory, or jurisdiction. Establishing a meaningful scholarly engagement under such conditions can be difficult. The writing workshop model that we describe in this article is interesting as an attempt to foster such engagement, and as a potential way to avoid creating an(other) 'empty' or meaningless network.

In this article we provide a detailed report on the writing workshop's methodology, and a commentary on that report which draws on our experience. ${ }^{13}$ Between the three of us, we have taken part in writing workshops run by the IGLP in different ways many times, and when we designed and convened the ATLAS Agora in Melbourne we ran the same model again there. The level of detail given in our report about these writing workshops is both designed to explain it enough to sustain the reflection, but also to allow for mimicry and experimentation should readers wish to try out the model. Although it derives from elite institutions, the model is not resource intensive and can be adapted to many contexts. To foreshadow our conclusions, our experience suggests that the unusually formal, even stylised, structure of the writing workshops offers participants both an opportunity for detailed feedback on their work, and can also help to foster a certain ethics of scholarly conduct. This is an ethics which places an unusual emphasis on the intimacy of scholarly relations, on the one hand, and on the significance to the practice of scholarship of

\footnotetext{
${ }^{12}$ As of June 2018, IGLP has so far hosted scholars from some 100 countries and more than 350 different universities: Institute for Global Law and Policy, Harvard Law School, Nurturing Innovative Approaches to Global Law and Policy 2010-2018 (online) <https://issuu.com/iglp/docs/iglp_compressed_fb_for_web?e=20778865/61323633> (last accessed 6 July 2018). ATLAS currently comprises nine members, Melbourne Law School having left the organisation in 2015. These are: the American University Washington College of Law, USA; Bar Ilan University, Israel; Bucerius Law School, Germany; Erasmus School of Law, The Netherlands; National University of Singapore, Singapore; Osgoode Hall Law School, Canada; Queen Mary University of London, UK; University College Dublin, Ireland; Université de Montréal, Canada. See American University Washington College of Law, SJD Program: Agora 2018 (online) <https://www.wcl.american.edu/academics/degrees/sjd/atlas-agora-2018/> (last accessed 6 July 2018).

${ }^{13}$ We thank the peer reviewer who suggested this formulation of what we are doing.
} 
listening, on the other. Our sense of this ethics is that it seems to work toward cutting across the substantive, educational, jurisdictional and, often, political divides that animate events such as those run by IGLP and ATLAS. More speculatively, we will suggest that this ethics may be antithetical to some of the more insidious imperatives of the contemporary university, and therefore important to nurture.

Our observations are complicated by what is often the elite institutional context of such events, and the fierce competition to gain access. These factors can, and visibly do, shape desire in ways which make people keen to be trained, or 'disciplined' in the methods and modes on offer. And yet, our gambit is that although the workshops - and our experiences of them - do not 'run clean', ${ }^{14}$ there are elements of the model which may be helpful in crafting an academic praxis which responds to the increasingly postneoliberal configuration of today's universities. ${ }^{15}$

\subsection{The Model}

Each year since 2010 the IGLP at Harvard Law School has run an intensive residential symposium for junior faculty, doctoral and post-doctoral scholars from around the world. ${ }^{16} \mathrm{~A}$ lot happens at these events, including plenary lectures, discussion panels and small group teaching, and the format is constantly being revised. Over time however, one anchor of the program has settled around a highly formalised 'writing workshop' in which, under the guidance of a faculty moderator, participants receive comments on a piece of writing both from IGLP faculty and each other. Feedback on these writing workshops has been almost uniformly positive. Participants regularly name them as the highlight of their event. The model is unusual, and highly specific. Based on our experience of the IGLP writing workshop, when Melbourne Law School hosted the ATLAS annual 'Agora' in 2014 we adapted it, and ran our own version. ${ }^{17}$

\footnotetext{
14 This is a reference to Gayatri Spivak, A Critique of Postcolonial Reason: Toward a History of the Vanishing Present (Harvard University Press 1999) 2.

${ }^{15}$ On post-neoliberalism, see Richard Denniss, 'Dead Right: How neoliberalism ate itself and what comes next' (2018) 70 Quarterly Essay 1.

${ }^{16}$ Institute for Global Law and Policy above note 12.

17 Melbourne Law School was a member of ATLAS from 2008 to 2015. For the history of the organisation, see Bevans and McKay above note 4. We informally sought permission from the IGLP's writing workshop designers, Daniel Brinks, Karen Engle and David Kennedy, to adapt the model to our event. Based on her experience of the Agora, Bronwen Morgan adapted the format to an Early Career Research workshop at the University of New South Wales.
} 


\subsection{The Method ${ }^{18}$}

The IGLP writing workshops were originally developed at the same time as the residential symposium began, by David Kennedy, ${ }^{19}$ Karen Engle ${ }^{20}$ and Daniel Brinks, ${ }^{21}$ though the format has evolved to its present form over several years. In their current form, each group comprises 8-10 participants, a moderator and (usually) two faculty commentators, all of whom meet (as a group) for two hours at a time over the 4-6 days of the residency. In each session, the group discusses the work of two participants, which has been circulated and read in advance. The procedure for this discussion is highly regulated, meaning that moderators are well briefed in advance and prepared for some strict time-keeping. At the IGLP Workshop, participants are also inducted into the writing workshop method through an introductory plenary session that introduces the writing workshop and emphasises the importance of fidelity to the method. Each paper is given 55 minutes, to be divided as follows. First, the paper's author has two minutes for a very brief introduction. The point here is not to summarise or justify their piece, but rather to frame and situate it for the group. Is it an excerpt from a dissertation, the first draft of a journal article or a late iteration of a book chapter? What is the broad literature with which it engages? To whom is it meant to speak? Are there any issues on which the author would particularly like feedback? How, in other words, can the group be helpful?

Once the paper has been framed for the group in this way, the author is not permitted to speak again until the very end of the session, even if they feel they have been egregiously misunderstood. The next twelve minutes fall to a peer discussant who has been tasked in advance with providing a summary of and constructive feedback on the piece. Again, the instructions are quite explicit: five minutes to describe the paper and identify its central argument(s) or contribution(s), two minutes on the mode of scholarly intervention, and another five minutes for constructive feedback. The key thing here is for the peer discussant to read and respond to the paper on its own terms rather than, say, explain what they would have done differently had they written the paper themselves or argue the merits of a different project

\footnotetext{
${ }^{18} \mathrm{~A}$ full description of the method - the one given to participants in the writing workshops - is available on the IGLP website. See Institute for Global Law and Policy, The IGLP Approach (online) 12 July 2017 <http://iglp.law.harvard.edu/the-iglp-approach-to-presenting-and-offering-feedback-at-writing-workshops/> (last accessed 6 July 2018).

${ }^{19}$ Manley O. Hudson Professor of Law; Director, Institute for Global Law and Policy, Harvard Law School.

${ }^{20}$ Minerva House Drysdale Regents Chair in Law; Founder and Co-Director, Bernard and Audre Rappaport Center for Human Rights and Justice, The University of Texas at Austin School of Law.

${ }^{21}$ Associate Professor; Co-Director, Bernard and Audre Rapport Center for Human Rights and Justice, The University of Texas at Austin School of Law.
} 
entirely. So in order to encourage feedback in this vein - and guide people as to how to offer it - some 'questions to consider when describing the paper' along with a list of possible ways to characterise the 'mode of intervention', and styles of constructive feedback are provided to participants in advance. Next the faculty commentators have six minutes each to give their thoughts on the paper, before finally the discussion is opened to the rest of the group, each of whom is required to comment at least once. Only at the end of the 55 minutes is the author allowed a very short response before the roles are reversed: after a quick break, the author becomes a peer discussant and vice-versa and the process begins again.

In reflecting on the model, it is helpful to consider each of the key roles performed at the workshop.

\subsection{Authors}

The most distinctive feature of the IGLP writing workshops structurally speaking is that they are fundamentally - even radically - feedback oriented. For authors this means a lot of comments, from a range of perspectives, in quick succession. Considering that a standard academic conference rarely allows for more than about five or ten minutes of discussion following individual oral presentations, and that even this short time is all too easily hijacked or frittered away, the sheer volume and diversity of feedback tends to be sincerely appreciated. Initially though, it can also be confronting. Certainly for the two of us who have taken part as authors it was. Not only is there a lot of information to digest, for many participants it is challenging to be given feedback on their work without a right of reply. This is a vulnerable position to be in, particularly for junior academics and PhD students whose confidence may already be fragile. It can be frustrating to feel misread or misunderstood and then not be permitted to set the record straight. There is a risk, therefore, that authors feel attacked.

From our experience, two factors seem to push against the risk of feeling (and indeed being) attacked. First, the position of being the 'author' rotates amongst the group. This seems to produce empathy with the particular author in the hot seat. Commenters either know already what it feels like to be in the author's position or that it will be their turn soon. Second, because the author's silence is enforced, and because they are so dramatically outnumbered, the power differential is clear from the structure. Not only is the author vulnerable, everyone knows it. Reciprocity ensures everyone feels it. In our experience the combination of these two characteristics often produce a particular atmosphere in the room which tends to be more intimate and supportive than in non-reciprocal and less structured instances of sharing work in progress, and in doing so shapes how participants deliver their feedback. 
Under such conditions, the risk of producing discomfort seems worth taking. The certainty of reciprocity encourages people to respond with generosity and care. ${ }^{22}$ In minimising the opportunities for the author to respond, the model both takes pressure off the author, and minimises opportunities for the author to respond defensively. By relieving authors of the burden of having to formulate an immediate and possibly hasty response, they are freed up to devote their whole attention to the substance of their feedback instead. In our experience, because of these elements, the model helps to foster an openness to critique which is important to improving academic work, but which can be hard both to cultivate in others, and to learn oneself at all stages of scholarly life.

\subsection{Peer discussants}

Unlike a conference setting where scholars present their own work, in this model, the author is not allowed to introduce the paper herself beyond a five-minute description of its genre, stage and context. Instead, the person responsible for providing the central account of the paper in this model is the 'peer discussant'. This feature of the model tends to strike the uninitiated as unusual (and sometimes at first 'unfair'), particularly given that the peer discussant is typically a stranger who may not share the author's precise disciplinary training or substantive field of research. On one level this is an extension of the workshop's general orientation towards feedback over exposition. It implies that as far as possible, each piece of writing is to be taken on its own terms and required to speak for itself, as it would be following publication, for example. But there are also several more specific features and forms of training that this way of proceeding enacts. For authors the experience of having their work described back to them - with all the translations and ellipses that inevitably entails - often proves unexpectedly illuminating, perhaps more than the subsequent critique. Listening to the peer discussants present the paper emphasises for authors how they are writing to be read and understood by an audience wider than immediate supervisors or colleagues. And for peer discussants the exercise is of explicit pedagogical value too, providing a practical training in reading, synthesis, exegesis and providing critical feedback. The ability to read, synthesise and critique another academic's work is a crucial aspect of scholarship, but such skills are

\footnotetext{
${ }^{22}$ We have seen exceptions to this, and the response of the group has been instructive. In our experience, people tend to show solidarity with the person under 'attack', in different ways. 'Faculty commentators' can also be key in asserting a counterweight to unfair, unkind and inappropriately delivered criticism, particularly if there seems to be an element of 'othering' at play.
} 
seldom explicitly modelled or taught. ${ }^{23}$ The writing workshop thus provides a forum in which both to practise and observe others practising. By virtue of the very detailed instructions provided, direct guidance is provided in this respect, which is very rare.

In our experience, peer discussants tend to take their role very seriously. This could be due to many factors. The self-selection, competitive application process and status of the host institutions combine to arrange the desires of participants in ways which perform an enforcement function. But it seems that the demands of the format itself, and the detailed instructions given, are just as important to the way people respond. Because the introduction must be delivered in person - to the author and in front of the group - and because the task is reciprocal, in that the roles are immediately reversed-peer discussant partners visibly demonstrate that they feel a real sense of responsibility towards each other. In most cases the result of this responsibility seems to be an assiduous précis of the author's argument along with productive criticism, delivered sensitively, and sincerely appreciated as a result.

\subsection{Commentators}

In this model, when they are not taking their turn as author and peer discussant, the other group members are positioned explicitly to listen to and learn from each other's comments, as well as to give their own. The model tries to strike a balance between observational learning and participation. Several features of the workshop's design militate against participants sitting back and letting the experience wash over them. First, the format is structured around an essential quid pro quo: for each participant, receiving quality feedback herself depends on the rest of the group providing it and vice versa. The explicit requirement that every participant comment at least once on each paper serves two functions which are also quite hard to ensure, but which can make or break such exercises. The first is that it works effectively to guarantee a minimum of preparation. The second is it reduces the chances of any individual dominating. The 'dominating individual' can often be thought of as self-important, but such dynamics may have more insidious structural reasons at play, such as gender or race. The 'rules' can be empowering, as they give the moderator, or 'convenor' not only licence but the duty to ask to hear from those who have not yet spoken. The flip side of this is that the commentators who feel they have nothing of value to offer, or who may be reluctant to speak, are obliged to offer comment and given guidelines to help them. In our

\footnotetext{
${ }^{23}$ Rosemary Caffarella and Bruce Barnett, 'Teaching Doctoral Students to Become Scholarly Writers: the importance of giving and receiving critiques' (2000) 25 Studies in Higher Education 39; Therese Ferguson, 'The "Write" Skills and More: A Thesis Writing Group for Doctoral Students' (2009) 33 Journal of Geography in High Education 285.
} 
experience, the combination of requirement and guidance can help overcome nerves and foster creative thinking. Like many of the workshop's more stringent features, we have observed that what may initially be experienced as an imposition, or 'micro-management', often proves liberating in practice. The mandating of at least one comment from each person seems to free participants from the obligation to speak only when they feel they have something 'important' to say (by whose standards?) and so encourages a certain critical ingenuity. If a commentator is struggling to engage with a paper's substance - perhaps it is not in their core field of expertise or employs a method with which they are not familiar they show themselves to be creative about what they can say about it. Participants make what are often constructive comments on the paper's style, structure or form, or use of disciplinary vernaculars. Having instructions which explicitly discourage participants from asking questions which are veiled versions of an account of how they would do the project force people to reshape their feedback in ways that do not suggest the author simply swap one theory, method or politics for another.

The group size means that participants necessarily spend much longer listening to each other's comments on a paper than they do commenting themselves. This also seems to us to have a few important effects. Most significantly perhaps, it invites a degree of critical engagement with the substance and style of the feedback being given. The pedagogical value of this aspect, of the format for the group as a whole, is perhaps most pronounced when it comes to the faculty commentators. Usually, faculty commentators are the most experienced people in the room when it comes to providing feedback on early-career academics' writing. Participants therefore have an opportunity to witness and reflect on the nature and delivery of the faculty commentators' feedback, an experience that is exceptionally rare outside the context of doctoral supervision, where supervisees are often too close to their writing to adopt the kind of critical perspective this workshop offers. The result of all this seems to be that the comments are never just for the author but also for the benefit of the rest of the group. In our experience, such training effectively happening each day during a multi-day residential Institute - sometimes means that feedback perceptibly improves as the workshop progresses.

\subsection{Scholarly Ethics: A Training in Conduct}

The writing workshop model described above offers training in a number of important academic skills. At the most superficial level it is about getting feedback on a draft chapter or journal article: a lesson in scholarly writing and argument. As we have seen, it is also a 'skills development' exercise of a relatively uncommon kind, providing explicit instruction and practice in a set of exercises requiring the description 
and critique of another scholar's work, even when that work is in an unfamiliar field. In our experience, these features alone would make the workshops worth running. But what makes this model particularly interesting, we argue, is that it also seems to do something else. The writing workshops have proven unusually effective at fostering certain modes of conduct and ways of relating to each other as scholars or scholarly ethics - that can be difficult to cultivate in the contemporary university. ${ }^{24}$ This is not the place to elaborate a full account of the ethics of scholarship, nor a critique of the contemporary university, but when we say ethics here we are talking about something quite different from the proliferating codes, policies and doctrines that govern, or claim to govern, the conduct of research. ${ }^{25}$ Indeed, we are talking about just the opposite; about conduct, rather than compliance. In the tradition we are enjoining in our commentary, ethics is precisely irreducible to the register of law, rule or doctrine. On this account, ethics is not a code, but an optics, 'a way of seeing and relating to others' ${ }^{26}$ not so much a science as a sensibility, an 'art of self-fashioning' as Foucault put it, ${ }^{27}$ mediated to some extent by the exigencies of one's role or office as a scholar. ${ }^{28}$ What we want to suggest is that this model of conducting a writing workshop is particularly good at cultivating at least two dimensions of an ethics of scholarship, which we are calling 'scholarly intimacy', on the one hand, and 'scholarly listening', on the other.

\subsection{Scholarly intimacy}

As we have already suggested, one of the most striking aspects of the writing workshops, both for participants and faculty in our experience, is the peculiar - and peculiarly constructive - atmosphere they

${ }^{24}$ Claire Aitchison, 'Writing Groups for Doctoral Education' (2009) 34 Studies in Higher Education 906; André Grace et al, "'Thinking the Practice": academic adult educators' reflections as a multicultural learning journey for graduate students' (2003) 25 Studies in Continuing Education 51; Barbara Grant, 'Mapping the Pleasures and Risks of Supervision' (2003) 24 Discourse: Studies in the Cultural Politics of Education 175; Bill Green, 'Unfinished Business: Subjectivity and Supervision' (2005) 24 Higher Education Research and Development 151.

25 European University Institute, Code of Ethics in Academic Research (online) 2013 <https://www.eui.eu/Documents/ServicesAdmin/DeanOfStudies/CodeofEthicsinAcademicResearch.pdf> (last accessed 13 July 2018); Ronald Collins, 'A Letter on Scholarly Ethics' (1995) 45 Journal of Legal Education 139.

${ }^{26}$ Desmond Manderson, Proximity, Levinas, and the Soul of Law (McGill-Queen's University Press 2006) 52.

${ }^{27}$ Michel Foucault, Ethics: Subjectivity and Truth (trans Robert Hurley) (New Press 1997); Michel Foucault, The Care of the Self: The History of Sexuality, Volume III (trans Robert Hurley) (Vintage Books 1986); Wesley Pue, 'Educating the Total Jurist' (2005) 8 Legal Ethics 208.

${ }^{28}$ Ann Genovese, 'On Australian Feminist Tradition: Three Notes on Conduct, Inheritance and the Relations of Historiography and Jurisprudence' (2014) 38 Journal of Australian Studies 430; Shaun McVeigh, 'Afterword: Office and the Conduct of the Minor Jurisprudent' (2015) 5 UC Irvine Law Review 499. 
generate. ${ }^{29}$ The experience is felt as both academically productive and rigorous, but it is also surprisingly intimate.

If intimacy seems like the wrong word to describe the relationship between academics in a formal setting who in most cases barely know each other and who, after all, are only commenting on each other's writing, we nevertheless want to suggest that it might be an appropriate one. In standard accounts, intimacy refers to a certain depth of connection. It is about closeness, ${ }^{30}$ 'mutual knowledge', ', 'sharing at the emotional level', ${ }^{32}$ and as a result the word tends to be reserved for the private sphere. ${ }^{33}$ This is a far cry from the writing workshops we are describing. But there are other ways of thinking about intimacy which capture some of the atmosphere which the workshops seem to engender. Many scholars have criticised conventional accounts of intimacy for its dependence on and sedimentation of heteronormative ideals of association, affection and personhood, and especially sex and the marriage form. ${ }^{34}$ Intimacy, they argue, can be like this but it is not how it works when it comes to many of the queer and non-normative sexual practices to which these authors want to draw attention and valorise. In these and many other contexts, they argue, intimacy is often precisely 'impersonal' - a function of distance rather than closeness, risk as opposed to comfort - but is no less significant or worth having as a result. ${ }^{35}$

There are any number of situations in which this is the case. Leo Bersani and Adam Phillips cite the relationship between analyst and analysand in psychoanalysis, ${ }^{36}$ but we could equally think of doctor patient relations more generally, the relationship between interviewer and interviewee, between attendees of a victim's support group, or indeed any encounter between relative strangers where one or

${ }^{29}$ Gernot Böhme, 'Atmosphere as the Fundamental Concept of a New Aesthetics' (1993) 36 Thesis Eleven 113; Peter Sloterdijk, Bubbles: Spheres Volume I (Semiotext(e) 2011); Peter Sloterdijk, Globes: Spheres Volume II (Semiotext(e) 2014); Andreas Philippopoulous-Mihalopoulos, Spatial Justice: Body, Lawscape, Atmosphere (Routledge, 2015); Vangie Bergum, 'Relational Pedagogy. Embodiment, Improvisation and Interdependence' (2003) 4(2) Nursing Philosophy 121.

${ }^{30}$ Christopher Lauer, Intimacy: A Dialectical Study (Bloomsbury Academic 2016).

${ }^{31}$ Ziyad Marar, Intimacy: Understanding the Subtle Power of Human Connection (Acumen Publishing 2012).

${ }^{32}$ William Masters, Virginia Johnson and Robert Kolodny, Heterosexuality (Harper Collins 1994) 18.

${ }^{33}$ Lauren Berlant, 'Intimacy' (1998) 24(2) Critical Inquiry 281.

${ }^{34}$ As above; Candace Vogler, 'Sex and Talk' (1998) 24(2) Critical Inquiry 328; Lauren Berlant, 'A Properly Political Concept of Love: Three Approaches in Ten Pages' (2011) 26 Cultural Anthropology 683; Leo Bersani, 'Is the Rectum a Grave?' in Douglas Crimp (ed), Aids: Cultural Analysis/Cultural Activism (MIT Press 1987) 197; Leo Bersani and Adam Phillips, Intimacies (University of Chicago Press 2008).

${ }^{35}$ Bersani and Phillips as above. Candace Vogler talks about 'depersonalizing' intimacy: Vogler as above.

${ }^{36}$ Bersani and Phillips as above. 
more parties are required to expose themselves, even in the knowledge that this may backfire. ${ }^{37}$ Whatever the precise situation, the key thing for our purposes is that this act of exposure can be highly productive affectively speaking, ${ }^{38}$ and moreover that it has an ethical dimension; eros and ethics being closely linked. ${ }^{39}$ Provided it is not taken too far (and the formality of the encounter plays a vital protective role in this respect), exposure produces something - an atmosphere, a mood, an intensity of relation - that founds, or is at least capable of founding, a real connection and sense of responsibility between the parties; not in spite of the distance between them, not in spite of the risk involved, but because of it. And the intimacy in these workshops is not just between two people-author and commentator - but between all the commentators and each other. ${ }^{40}$

This is what we mean by intimacy: the peculiar affective and ethical bond that results from a willingness to make oneself vulnerable before strangers. ${ }^{41}$ More than anything in the written instructions or the manner, experience or skill of the moderator, at the writing workshops as we have experienced them this intimacy seems to be a function of their distinctive format: the author's silence and vulnerability, the uneven distribution of power, the fact that authorship rotates, and that comments and critique are always given in front of the rest of the group. Under these conditions, the sense of risk and mutual intellectual exposure is palpable in the room. And although in principle participants could react to this in any number of ways, our experience is that they overwhelmingly respond by banding together: by engaging sincerely with each other's work and by assuming responsibility for the substance and manner of their feedback. This doesn't always happen smoothly, particularly when people feel like outsiders to 'the network', or alienated by the (leftish) politics of the workshops we have participated in and run. This has observably happened both to those who feel themselves to be more politically radical, as well as more

${ }^{37}$ Emmanuel Levinas would say that we always expose ourselves in this way when we encounter the other, as the other does to us: Emmanuel Levinas, Otherwise than Being, or Beyond Essence (trans Alphonso Lingis) (Springer 1981); Emmanuel Levinas, Totality and Infinity (trans Alphonso Lingis) (Duquesne University Press 1969).

${ }^{38}$ Brian Massumi, Parables for the Virtual: Movement, Affect, Sensation (Duke University Press 2002); Melissa Greg and Gregory Seigworth (eds), The Affect Theory Reader (Duke University Press 2010); Baruch Spinoza, Ethics: On the Correction of Understanding (trans Andrew Boyle) (Dent 1959).

${ }^{39}$ Foucault 1986 above note 27; Kerry Burch, Eros as the Educational Principle of Democracy (Peter Lang 2000); Deborah Britzman, 'Teachers and Eros' (2010) 10 Sex Education 325; bell hooks, Teaching to Transgress: Education as the Practice of Freedom (Routledge 1994).

${ }^{40}$ Thanks to one of the anonymous referees for drawing this out, and its relation to disruptive accounts of intimacy and polyamory.

${ }^{41}$ Branko Kulevski, 'The Educative Eros: Teacher-Pupil Intimacy and Aspects of Pedagogic Domination in Plato's Academy' (1984) 13 History of Education Review 14; Emma Bell and Amanda Sinclair, 'Reclaiming Eroticism in the Academy' (2014) 21 Organization 268; Michalinos Zembylas, 'Risks and Pleasures: a Deleuzo-Guattarian Pedagogy of Desire in Education' (2007) 33 British Educational Research Journal 331. 
jurisprudentially conservative or doctrinally oriented than their perception of the complicities or politics of the Institute as a whole. And yet even when the workshops fail as a ritual of community, our experience in terms of how people engage with each other as scholars, is that comments tend not only to be of a high quality but to be delivered sensitively, in a spirit of generosity, and with an ear for tone which often improves over the course of the meetings. In other words, the intimacy of the workshops has an observable effect on the way participants conduct themselves towards each other as scholars.

This scholarly intimacy, we argue, is something more than simple collegiality or academic civility. But it is also neither intellectual community nor friendship, both of which depend on some sort of interpersonal knowledge and sense of belonging, either real or imagined. It is perhaps a form of what Derrida would call 'hospitality', ${ }^{42}$ a way of relating to and caring for one's fellow scholars and their work that proceeds from the knowledge and experience of their vulnerability: this sense that what we say and how we say it to each other as scholars matters, and that our intellectual, emotional and ethical lives are profoundly connected. In our experience, this is one of the key elements this model of writing workshop seems to offer: an experience of the intimacy of scholarship and of the diverse responsibilities that flow from that office. $^{43}$

\subsection{Scholarly listening}

In our argument, listening too is ethical. Whereas hearing is a physiological phenomenon, in the sense that it can be explained 'by recourse to acoustics and to the physiology of the ear', ${ }^{44}$ listening is a psychological act: a practice, an attitude, a way of relating to others and of being in the world. ${ }^{45}$ In the context of scholarship, we can think about this practice in a number of different ways.

To a large extent, scholarly listening is about openness: both to ideas in general and to critiques of one's work. To listen, in this sense, is to refrain from having already decided: to be ready and willing to reform one's thinking, to refuse to rush to judgment. 'Anyone who listens', as Hans-Georg Gadamer puts it, 'is fundamentally open'. ${ }^{46}$ And for Gemma Corradi Fiumara, 'unless we are ready, receptive - and also,

\footnotetext{
42 Jacques Derrida and Anne Dufourmantelle, Of Hospitality (trans Rachel Bowlby) (Stanford University Press 2000).

${ }^{43}$ On the relationship between conduct, ethics and office, see McVeigh above note 28 and Genovese above note 9.

44 Roland Barthes, The Responsibility of Forms: Critical Essays on Music, Art, and Representation (trans Richard Howard) (Hill and Wang 1991) 245.

45 Jean-Luc Nancy, Listening (trans Charlotte Mandell) (Fordham University Press 2007).

${ }^{46}$ Hans-Georg Gadamer, Truth and Method (trans Garrett Barden and John Cumming) (The Seabury Press 1975$) 324$.
} 
possibly, vulnerable - the experience of listening appears to be impossible' ${ }^{47}$ In our experience, the formal strictures of this model of writing workshop seem to make possible this sense of receptivity by asking people to sit silently for close to an hour while others engage in detail with their work. The rigidity of the format gives authors permission to slow down, to sit and allow their feedback time to digest, rather than worry about formulating a response. If a similar point is being made consistently, perhaps there is something to it, even if it didn't seem that way at first. And in any case, the author's judgment can be deferred. What initially felt like a misreading may eventually mature into a productive insight. And if it doesn't, this can be worth noticing too. Where and why is the author being misconstrued? Can they take steps to prevent readers from making the same mistake in future? Or is this simply a lesson in an important truth of academic life? That their (our) work will not always be read and understood as they (we) would wish it to be, and that to some extent this is simply beyond their (our) control.

Being open to critique is not the same thing as abandoning one's critical faculties. Nor is scholarly listening about openness alone. One thing this model of writing workshop makes abundantly clear is that how one listens as a scholar is always mediated by who or what one is listening to and why. ${ }^{48}$ When participating in the workshops in any capacity, it is hard not to notice, for instance, the enormous difference between the listening position of authors, which is inevitably oriented more towards the substance of the comments being given, and that of the peer discussant and commentators, which invites more engagement with the style, genre and tone of these comments. For non-authors, that is, the question is not just do they agree, or did they think the same thing as they read the piece? But also: how well is the comment being articulated, what kind of critique is it, what is unfamiliar or striking about it, how does it sit alongside or in relation to your own thoughts, how would you rearticulate those thoughts now, might a similar critique apply to your own writing? Listening - the kind of listening facilitated by the workshop's design - becomes a method of self-reflection and critique: a way of thinking and re-thinking one's conduct as a scholar. What one does, how one does it and why, in the end, it matters. ${ }^{49}$

\footnotetext{
${ }^{47}$ Gemma Corradi Fiumara, The Other Side of Language: A Philosophy of Listening (Routledge 1995$) 191$.

${ }^{48}$ Ola Stockfelt, 'Adequate Modes of Listening' in Christoph Cox and Daniel Warner (eds), Audio Culture: Readings in Modern Music (Continuum 2004) 88; Jonathan Sterne, The Audible Past: Cultural Origins of Sound Reproduction (Duke University Press 2003).

49 Peter Szendy, Listen: A History of Our Ears (trans Charlotte Mandell) (Fordham University Press 2008$) 148$.
} 


\subsection{Conclusions}

The methodology we have described here bears a complex relation to everyday practices of scholarly selffashioning. It does serve a disciplining function as the ritualised 'embodiment of a pedagogy ... of the reading and writing practices of a community'. ${ }^{50}$ And yet we have observed that the highly formalised structure of the workshops is experienced by the participants as producing a certain freedom because it reduces the generalised anxieties attached to giving and receiving feedback in a relatively high stakes environment. Perhaps because it shapes desire in a controlled form, the method seems to allow participants space to practice the intimacy and listening we are describing here. One way then of thinking of institutional forms like the highly structured writing workshop is in relation to the broader academic project.

Together, the tangled forces of neoliberalism, managerialism and so-called 'Knowledge' or 'Academic' Capitalism ${ }^{51}$ mean that 'academics are constantly being exhorted to do more with less-to teach more students, generate more research moneys and produce more 'outputs' ... all this while assuming greater administrative burdens themselves. ${ }^{\prime 52} \mathrm{~A}$ whole range of scholars have pointed to the corrosive effects of such pressures on both the nature of scholarship and the idea of the university as a public good, and have argued for the importance of resistance within the academy as a result. ${ }^{53}$ As a training in conduct, and practice of the cultivation of a certain ethics, the model we have described does not fit neatly on the spectrum between left and right, nor position itself as a form of resistance to power. Instead, in the guise of a 'writing workshop', it invites attention to the office of the scholar and it could easily be adapted to a

${ }^{50}$ Threadgold above note 10 at 280.

${ }^{51}$ Alan Burton-Jones, Knowledge Capitalism: Business, Work, and Learning in the New Economy (Oxford University Press 1999); Sheila Slaughter and Larry Leslie, Academic Capitalism: Politics, Policies and the Entrepreneurial University (John Hopkins University Press 1997).

${ }^{52}$ Margaret Thornton, 'Inhabiting the Neoliberal University' (2013) 38 Alternative Law Journal 72.

53 John Henry Newman, The Idea of a University: Defined and Illustrated (Oxford University Press 1976); Margaret Thornton, 'Universities Upside Down: The Impact of the New Knowledge Economy' (2009) 21 Canadian Journal of Women and the Law 375; Thornton above note 3 at 19; Brian Denman, 'What is a University in the 21st Century?' (2005) 17 Higher Education Management and Policy 9; Stefan Collini, 'The War on Universities: How the Pursuit of Truth is Under Threat' New Statesman (online) 4 July 2011 <https://www.newstatesman.com/books/2011/07/university-universities> (last accessed 8 July 2018); Alison Mountz et al, 'For Slow Scholarship: A Feminist Politics of Resistance through Collective Action in the Neoliberal University' (2015) 14(4) ACME: An International E-Journal for Critical Geographies 1; Maggie Berg and Barbara Seeber, The Slow Professor: Challenging the Culture of Speed in the Academy (University of Toronto Press 2016). 
whole range of pedagogical contexts since its main intervention is to insist on the importance of scholarly conduct per se. 


\section{University Library}

\section{- M M N E R VA A gateway to Melbourne's research publications}

Minerva Access is the Institutional Repository of The University of Melbourne

Author/s:

CHIAM, M;Pahuja, S;Parker, J

Title:

How To Run a Writing Workshop? On the Cultivation of Scholarly Ethics in 'Global' Legal Education'

Date:

2018

Citation:

CHIAM, M., Pahuja, S. \& Parker, J. (2018). How To Run a Writing Workshop? On the Cultivation of Scholarly Ethics in 'Global' Legal Education'. Australian Feminist Law Journal, 44 (2), pp.289-302. https://doi.org/10.1080/13200968.2018.1504608.

Persistent Link:

http://hdl.handle.net/11343/251327 